\title{
Variations in morphological traits of bermudagrass and relationship with soil and climate along latitudinal gradients
}

\author{
Jingxue Zhang ${ }^{1}$, Miaoli Wang ${ }^{1}$, Zhipeng Guo ${ }^{1}$, Yongzhuo Guan', Yuxia Guo ${ }^{1 *}$ and Xuebing Yan²*
}

\begin{abstract}
Background: This complex environmental heterogeneity coupled with the long-standing history offers scenario suitable for and favoring the evolution and existence of variation of morphological traits.

Methods: In this study, we measured 10 morphological traits of 310 Cynodon dactylon individuals sampled at 16 different locations along latitudinal gradients between $22^{\circ} 35^{\prime} \mathrm{N}$ and $36^{\circ} 18^{\prime} \mathrm{N}$ to reveal phenotypic plasticity influenced by latitude. In addition, the relationships between morphological variation and soil nutrient and climate factors were analyzed.

Results: Analysis of variance, divesity examination and Mantel correlation test detected a significant effect of latitude on morphological traits. Cluster analysis and principal component analysis clearly separated the selected populations into four groups according to latitude. Larger morphological sizes of $C$. dactylon appeared at the lowand high-latitude regions. Correlation analysis indicated that high morphological variations were significantly correlated with climate factors and soil nutrient.
\end{abstract}

Conclusion: This study suggests morphological variation of wild bermudagrass is greatly influenced by latitude as well as soil and climate, which could be useful resources for genetic studies and evolution.

Keywords: Cynodon dactylon, Morphology, Variation, Latitude, Soil nutrient

\section{Background}

Morphological plasticity may be of critical importance for resource acquisition by plants [1]. They change their growth form to become more flexible in favorable habitat. The morphological and developmental diversity between taxa and within each taxon is vast. Phenotypic variation observed for plants is generally a response to differences in climatic conditions that reflects adaptive evolution and phenotypic plasticity [2-6]. The Cynodon species is enormously variable and has become truly cosmopolitan which is originated and diversified somewhere from West Pakistan to Turkey(i.e., Turkey, Iran, Afghanistan and the West part of Pakistan) and distributed in all countries and islands between about lat $45^{\circ} \mathrm{N}$ and lat $45^{\circ} \mathrm{S}$ and penetrates to approximately lat $53^{\circ} \mathrm{N}$ in Europe. Perennial Bermudagrass [Cynodon dactylon

\footnotetext{
* Correspondence: yuxiaguo@163.com; yxbbjzz@163.com

${ }^{1}$ College of Animal and Veterinary Science, Henan Agricultural University, Zhengzhou 450002, China

${ }^{2}$ College of Animal Science and Technology, Yangzhou University, Yangzhou 225000, China
}

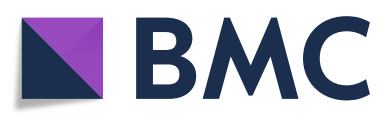

(c) The Author(s). 2018 Open Access This article is distributed under the terms of the Creative Commons Attribution 4.0 International License (http://creativecommons.org/licenses/by/4.0/), which permits unrestricted use, distribution, and reproduction in any medium, provided you give appropriate credit to the original author(s) and the source, provide a link to the Creative Commons license, and indicate if changes were made. The Creative Commons Public Domain Dedication waiver (http://creativecommons.org/publicdomain/zero/1.0/) applies to the data made available in this article, unless otherwise stated. and morphologically diverse warm-season grass widely used for pasture, forage, turf grass, soil stabilization, and remediation $[7,8]$. Over the past decades, several studies have examined morphology, physiology, and biochemistry in order to assess the diversity of $C$. dactylon [9-12]. There is enormous morphological variability among the nine recognized Cynodon species [13]. Australia is third to Africa and Asia respectively in terms of Cynodon species diversity and seven Cynodon species currently were recognized in the Australian Biological Resources Study [14, 15]. Bermudagrass is widespread in Italy under different ecological situations, and there was wide variation in wild populations concerning morphological traits of potential interest for turf use, such as leaf size and growth habit [16].

Geographical or environmental gradient exerts the strongest adaptive selection on some related variation both in genetic structure and phenotypic traits of a species. Many of these factors include temperature, precipitation, soil nutrient 
availability, growing season length, photoperiod and biotic agents are directly affected by geographic position or elevation, and are therefore interrelated. Such latitudinal gradients in species richness are among the most universal features of nature and have been discussed by many authors $[17,18]$. Changes in latitude have a drastic effect on the physical, chemical, and biological properties of soil and hence change the quality of soil. Regeneration and growth of vegetation occurred successfully are affected by a variety of conditions of soil [19]. It is well known that $\mathrm{N}$ transformations are affected by a number of soil properties, including mineralogy and texture, organic matter quantity and quality, $\mathrm{pH}$, moisture, and microbial population size [20], and these soil properties can vary considerably from one turfgrass system to another [21, 22]. Soil organic matter is an important component of soil, and microbial biomass is the living and active part of the soil organic matter, the source and sink of available nutrients, builds up with increased accumulation of organic matter during soil development [23-26]. Some types of reactive $\mathrm{N}$ (e.g., $\mathrm{NH}_{4}{ }^{+}$and $\mathrm{NO}_{3}{ }^{-}$) are essential to plant growth and ecosystem productivity. Due to the direct relationship between soil nutrients and quality, it is closely linked to the primary productivity of the ecosystem [27], and responsible for the nutrient cycling and development and function of the soil system [28, 29]. Latitudinally-defined climate conditions may provide specific Cynodon types and soil environments. The optimal resolution at which soil and Cynodon variables should be sensed and treated is not well defined. Scientific information on the variability and distribution of soil properties is critical for understanding ecosystem processes and making sustain-able soil, crop, and environmental management decisions [30, 31]. Strategic sampling of Cynodon at simply different latitude has not been conducted in China and the collection is expected to include valuable germplasm for Cynodon improvement and research. The objectives of this study were: (1) to examine morphological variability of Cynodon along latitude gradient; (2) to determine if and how differences in morphological traits of Cynodon were correlated with climate factors and soil nutrient. This information will facilitate the future use of germplasm in Cynodon breeding, genomics, conservation, taxonomy, and phylogeographical research and evaluate accurately whether natural selection and migration may allow evolutionary responses for populations to sufficiently match their new climates.

\section{Methods}

\section{Plant materials and morphological evaluation}

A total of 310 individual plants of $C$. dactylon, comprising of root and stem with a spacing of at least $50 \mathrm{~m}$ apart among each individual, were separately collected from 16 sites at different latitudes between $22^{\circ} 35^{\prime} \mathrm{N}$ and $36^{\circ} 18^{\prime} \mathrm{N}$ with similar longitude in China (Table 1). The morphological traits of each bermudagrass plants were examined on the collection site, including leaf length, leaf width, internode diameter, internode length, turf height, and reproductive branch height during August 2015. The longest leaf at the third node below the apical meristem of the stolon and erect shoot was used for the measurement of leaf length $(\mathrm{mm})$ and leaf width $(\mathrm{mm})$ with vernier calipers. Additionally, random stolons and erect shoots on each site were measured for internode length $(\mathrm{mm})$ and diameter $(\mathrm{mm})$ between the third and fourth fully extended nodes from the apical meristem. Turf height $(\mathrm{mm})$ and reproductive branch height $(\mathrm{mm})$ were determined quantitatively on each site. Total annual precipitation, mean annual temperature, annual maximum and minimum temperature of each collection location were provided by the China Meteorological Administration (Table 1).

\section{Soil nutrients evaluation}

Soil samples $(0-20 \mathrm{~cm}$ depth) were collected separately under the canopy of the different plant of $C$. dactylon in twenty random quadrats $(10 \mathrm{~m} \times 10 \mathrm{~m})$ at each site in August 2015. In each quadrat, the soil was randomly collected with five replicates. After carefully removing the surface organic materials and fine roots, the soil sample was air-dried at $25{ }^{\circ} \mathrm{C}$ room temperature for the estimation of soil physicochemical properties, exclusive of plant residues and ground to pass through $2 \mathrm{~mm}$ nylon sieves for analyzing Available Nitrogen(AN), Soil Organic Matter (SOM), Total Nitrogen (TN), pH, exchangeable $\mathrm{Ca}, \mathrm{Na}, \mathrm{Mg}$ and Available Kalium(AK). Chemical analyses were conducted following the methodologies [32]. The AN, SOM, TN and AK were measured using the Kjeldahl method, the potassium dichromate wet combustion procedure (Agricultural Chemistry Committee of China, 2006), Kjeldahl method (Agricultural Chemistry Committee of China, 1987) and flame emission spectrometry (Agricultural Chemistry Committee of China, 2004), respectively. Soil pH was measured with a glass electrode, samples having been diluted with water (the ratio of soil to water was 1:2.5). Exchangeable $\mathrm{Ca}, \mathrm{Mg}$ and $\mathrm{Na}$ concentrations were determined on continuum-source atomic-absorption spectrometry (SpectrAA20 Varian) with soil extracts.

\section{Statistical analysis}

One-way analysis of variance (ANOVA) procedures were used to test significant differences in soil properties, morphological characters of $C$. dactylon among latitudinal gradients. We also used morphological data to calculate Shannon-Wiener index by using software package Popgen 32 to evaluate the variation frequency and degree of variation of morphological traits of different geographical groups. The geographical distance matrix was calculated by using the arc distance between each pair of sites based on the latitude and longitude of locations. 
Table 1 C. dactylon populations collected from different latitudes in China

\begin{tabular}{|c|c|c|c|c|c|c|c|c|}
\hline $\begin{array}{l}\text { Population } \\
\text { code }\end{array}$ & Localities & $\begin{array}{l}\text { Altitude/ } \\
\text { m }\end{array}$ & Latitude & Longitude & $\begin{array}{l}\text { Annual average } \\
\text { temperature } /{ }^{\circ} \mathrm{C}\end{array}$ & $\begin{array}{l}\text { Annual maximum } \\
\text { temperature } /{ }^{\circ} \mathrm{C}\end{array}$ & $\begin{array}{l}\text { Annual minimum } \\
\text { temperature } /{ }^{\circ} \mathrm{C}\end{array}$ & $\begin{array}{l}\text { Annual average } \\
\text { precipitation/mm }\end{array}$ \\
\hline 1 & Cixian & 130 & $36^{\circ} 18^{\prime} 40^{\prime \prime}$ & $114^{\circ} 11^{\prime} 51^{\prime \prime}$ & 13.4 & 19.5 & 7.9 & 509.2 \\
\hline 2 & Huixian & 120 & $35^{\circ} 29^{\prime} 26^{\prime \prime}$ & $113^{\circ} 48^{\prime} 23^{\prime \prime}$ & 14.6 & 20.3 & 9.8 & 586.9 \\
\hline 3 & Zhengzhou & 90 & $34^{\circ} 54^{\prime} 04^{\prime \prime}$ & $113^{\circ} 38^{\prime} 20^{\prime \prime}$ & 14.7 & 20.3 & 9.9 & 640.8 \\
\hline 4 & Xuchang & 90 & $34^{\circ} 00^{\prime} 30^{\prime \prime}$ & $113^{\circ} 45^{\prime} 23^{\prime \prime}$ & 14.6 & 20.3 & 9.9 & 733.5 \\
\hline 5 & Zhumadian & 50 & $33^{\circ} 09^{\prime} 47^{\prime \prime}$ & $114^{\circ} 03^{\prime} 45^{\prime \prime}$ & 15.2 & 20.4 & 10.7 & 990.4 \\
\hline 6 & Xinyang & 100 & $32^{\circ} 08^{\prime} 38^{\prime \prime}$ & $113^{\circ} 59^{\prime} 46^{\prime \prime}$ & 15.5 & 20.4 & 11.7 & 1106.1 \\
\hline 7 & Xiaochang & 50 & $31^{\circ} 18^{\prime} 59^{\prime \prime}$ & $114^{\circ} 02^{\prime} 15^{\prime \prime}$ & 16.8 & 21.3 & 13.4 & 1138.0 \\
\hline 8 & Xiantao & 30 & $30^{\circ} 25^{\prime} 48^{\prime \prime}$ & $113^{\circ} 26^{\prime} 05^{\prime \prime}$ & 17.0 & 21.2 & 13.8 & 1238.6 \\
\hline 9 & Linxiang & 60 & $29^{\circ} 28^{\prime} 32^{\prime \prime}$ & $113^{\circ} 26^{\prime} 48^{\prime \prime}$ & 16.8 & 21.5 & 13.4 & 1582.5 \\
\hline 10 & Liuyang & 90 & $28^{\circ} 09^{\prime} 14^{\prime \prime}$ & $113^{\circ} 33^{\prime} 42^{\prime \prime}$ & 17.5 & 22.5 & 13.8 & 1551.3 \\
\hline 11 & Youxian & 90 & $27^{\circ} 00^{\prime} 59^{\prime \prime}$ & $113^{\circ} 23^{\prime} 07^{\prime \prime}$ & 18.1 & 22.6 & 14.8 & 1518.4 \\
\hline 12 & Guidong & 810 & $26^{\circ} 03^{\prime} 49^{\prime \prime}$ & $113^{\circ} 56^{\prime} 34^{\prime \prime}$ & 15.8 & 21.6 & 12.1 & 1742.4 \\
\hline 13 & Renhua & 90 & $25^{\circ} 05^{\prime} 29^{\prime \prime}$ & $113^{\circ} 43^{\prime} 17^{\prime \prime}$ & 19.9 & 25.1 & 16.5 & 1660.9 \\
\hline 14 & Yingde & 50 & $24^{\circ} 10^{\prime} 31^{\prime \prime}$ & $113^{\circ} 22^{\prime} 08^{\prime \prime}$ & 21.2 & 25.8 & 18.1 & 1835.9 \\
\hline 15 & Guangzhou & 10 & $22^{\circ} 51^{\prime} 48^{\prime \prime}$ & $113^{\circ} 22^{\prime} 22^{\prime \prime}$ & 22.8 & 27.2 & 19.6 & 1906.8 \\
\hline 16 & Zhongshan & 0 & $22^{\circ} 35^{\prime} 40^{\prime \prime}$ & $113^{\circ} 23^{\prime} 17^{\prime \prime}$ & 22.0 & 25.9 & 19.1 & 1846.8 \\
\hline
\end{tabular}

Mantel correlation coefficients between morphological traits and geographical distance matrices were calculated by using NTSYSpc version 2.10e. For each morphological variable the observe values in different latitude were subjected to a Principal Component Analysis (PCA) and Cluster Analysis (CA) using Ward's method. Pearson's correlation coefficient was used to check the relationships between morphological traits and environmental characters. Statistical analysis was performed using the software package SPSS13.0 for Windows (SPSS Inc. Chicago, USA). Figures were generated by Sigmaplot 10.0 (Systat Software Inc.) and the R package.

\section{Results}

ANOVA analysis

Descriptive statistics including mean, maximum, minimum, standard deviation and coefficient of variation $(\mathrm{CV})$ for C. dactylon morphological data were given in Table 2. Analysis of data showed high morphological variability at different latitude. With regard to morphological traits, the $\mathrm{CV}$ values of leaf length, internodes length, turf height and reproductive branch height were relatively high. The $\mathrm{CV}$ analysis indicated that leaf length of stolon was the most variable morphological trait with a CV of $44.88 \%$ (Table 2). The leaf width and diameter were not significantly differentiated, with a CV equal approximately to $10 \%$. Also, Cynodon morphological diversity has been partly determined by calculating different morphological traits Shannon-Wiener index. During Cynodon morphological traits, range of Shannon-Wiener index within latitude was 1.53-1.87, while range of Shannon-Wiener index among latitude was 1.91-2.16 (Table 3). High values of Shannon-Wiener index of different morphological traits showed high morphological traits diversity. Different Shannon-Wiener index along latitude gradient indicates different degree of morphological diversity. Morphological traits were significantly different along the latitudinal gradient by ANOVA analysis, suggesting a notable effect of latitude on the morphological traits (Table 4). Significant variation was also found among different soil properties (Table 5), SOM showed the greatest variability with a CV of $79.59 \%$. In contrast, $\mathrm{pH}$ exhibited the lowest variability with a CV of $7.24 \%$.

\section{Cluster analysis}

PCA allowed us to find out which variables contribute most to the differences among groups (Table 6). The first two principal components (PCs) accounted for $67.47 \%$ of total variance. Dendrograms was used to graphically represent a hierarchical cluster analysis of the relationship between 16 populations based on bermudagrass morphological traits at different latitudes, respectively. From the cluster analyses, obvious effect of latitude on the morphological traits of common bermudagrass was observed. In dendrogram generated based on bermudagrass morphological traits, the 16 populations were separated into 4 clusters on the unweighted pair group mean average (UPGMA) tree (Fig. 1). This dendrogram showed that cluster A corresponded with middle latitude, cluster B corresponded with low latitude, cluster D corresponded with high latitude, while cluster C was the admixture group with low and high latitude. We attempted to estimate whether morphological traits and soil 
Table 2 Morphological features of the bermudagrass ecotypes used in the diversity analysis

\begin{tabular}{|c|c|c|c|c|c|}
\hline & Parameter & Minimum(mm) & $\operatorname{Maximum}(\mathrm{mm})$ & Mean \pm SD & $\mathrm{CV}(\%)$ \\
\hline \multirow[t]{4}{*}{ Erect shoot } & Leaf length & 23.72 & 69.82 & $41.34 \pm 12.91$ & 31.24 \\
\hline & Leaf width & 2.08 & 2.77 & $2.40 \pm 0.21$ & 8.80 \\
\hline & Internode length & 11.24 & 36.04 & $20.49 \pm 7.13$ & 34.80 \\
\hline & diameter & 0.73 & 1.04 & $0.86 \pm 0.09$ & 10.73 \\
\hline \multirow[t]{6}{*}{ Stolon } & Leaf length & 18.99 & 84.92 & $39.32 \pm 17.65$ & 44.88 \\
\hline & Leaf width & 2.24 & 3.03 & $2.55 \pm 0.25$ & 9.68 \\
\hline & Internode length & 22.24 & 55.39 & $38.97 \pm 10.04$ & 25.76 \\
\hline & diameter & 0.91 & 1.18 & $1.02 \pm 0.09$ & 8.45 \\
\hline & Turf height & 76.30 & 269.40 & $129.80 \pm 47.70$ & 36.74 \\
\hline & Reproductive branch height & 69.00 & 240.00 & $142.50 \pm 48.80$ & 34.21 \\
\hline
\end{tabular}

properties varied with latitudinal gradient. Based on the results, the distribution of morphological traits and soil properties within the 16 populations among the different latitudes was presented in Table 7. These four clusters were different mainly in morphological traits, with lower values in cluster A than in clusters B, C and D.

\section{Correlation analysis}

The results of the Mantel tests showed that morphological distance matrices were not significantly correlated with geographical distance matrix $(r=0.0370, P=0.6327)$. Most of the measured morphological traits at different latitude showed some kind of correlations with climate factors
(Table 8). Annual average precipitation negatively correlated $(P<0.01)$ with leaf length, diameter, turf height, reproductive branch height, internodes length of erect shoots and leaf width of stolon. As for annual average temperature, it significantly correlated with diameter, turf height, leaf length of stolon, and leaf width of stolon $(\mathrm{P}<0.01)$ and leaf length of erect shoots $(P<0.05)$. Beyond that, annual minimum temperature negatively correlated with reproductive branch height and internodes length of erect shoots $(\mathrm{P}<$ 0.05). There were positive relationships between climate factors and Diversity index. The similar distribution patterns of morphological traits and soil properties indicated their high correlation. Correlation coefficients between

Table 3 The Compare of diversity index in Morphological characters

\begin{tabular}{|c|c|c|c|c|c|c|c|c|c|c|}
\hline \multirow{2}{*}{$\begin{array}{l}\text { Population } \\
\text { code }\end{array}$} & \multicolumn{4}{|l|}{ Erect shoot } & \multicolumn{4}{|l|}{ Stolon } & \multirow{2}{*}{$\begin{array}{l}\text { Turf } \\
\text { height }\end{array}$} & \multirow{2}{*}{$\begin{array}{l}\text { Reproductive } \\
\text { branch } \\
\text { height }\end{array}$} \\
\hline & Leaf length & Leaf width & Internode length & Diameter & Leaf length & Leaf width & Internode length & Diameter & & \\
\hline 1 & 1.2799 & 1.2206 & 1.6434 & 1.8344 & 1.5048 & 1.6094 & 1.2799 & 1.6957 & 1.5048 & 1.6957 \\
\hline 2 & 1.7127 & 1.8082 & 1.8217 & 2.0331 & 1.8514 & 1.7820 & 1.6385 & 2.0558 & 1.5833 & 1.8082 \\
\hline 3 & 1.4956 & 1.6908 & 1.5275 & 1.7737 & 1.6788 & 1.3728 & 1.7651 & 1.9434 & 1.4708 & 0.9819 \\
\hline 4 & 1.6230 & 1.8605 & 1.6123 & 1.7771 & 1.6103 & 1.6230 & 1.7651 & 1.8174 & 0.9143 & 1.7219 \\
\hline 5 & 1.8605 & 1.8344 & 1.8479 & 1.7036 & 1.8047 & 1.9604 & 1.6957 & 1.7510 & 2.0162 & 1.6796 \\
\hline 6 & 1.8479 & 2.0558 & 1.8514 & 2.0162 & 1.5842 & 2.0685 & 1.8775 & 1.9434 & 1.6003 & 2.0558 \\
\hline 7 & 1.2773 & 1.9298 & 1.3274 & 1.8775 & 1.2488 & 1.5833 & 1.6782 & 2.0685 & 1.4956 & 1.5013 \\
\hline 8 & 1.8217 & 1.7524 & 1.5954 & 1.9831 & 0.9433 & 1.5430 & 1.4406 & 1.8945 & 1.7389 & 1.6696 \\
\hline 9 & 1.2206 & 1.5218 & 1.3308 & 1.6788 & 1.5430 & 1.7524 & 1.3285 & 1.6365 & 1.1611 & 1.2376 \\
\hline 10 & 1.8082 & 1.8945 & 1.5430 & 1.6788 & 1.4999 & 1.8741 & 1.9002 & 1.9172 & 1.6173 & 1.8183 \\
\hline 11 & 1.5099 & 1.8183 & 1.8444 & 1.8479 & 1.3047 & 1.9560 & 1.5410 & 2.0558 & 1.3308 & 1.6400 \\
\hline 12 & 1.8726 & 1.8082 & 1.9172 & 2.0685 & 1.7340 & 1.9865 & 1.9695 & 1.5353 & 1.8344 & 1.9865 \\
\hline 13 & 1.7524 & 1.6046 & 1.7820 & 1.9992 & 1.4878 & 1.9900 & 1.8741 & 2.0855 & 1.7693 & 1.6526 \\
\hline 14 & 1.9434 & 1.8217 & 1.8309 & 1.7912 & 1.5911 & 1.8444 & 1.7058 & 1.6604 & 1.8465 & 1.8775 \\
\hline 15 & 1.9434 & 1.7036 & 1.9434 & 1.9158 & 1.5260 & 1.9865 & 1.9730 & 1.3728 & 1.4878 & 1.7524 \\
\hline 16 & 1.5833 & 1.5911 & 1.8867 & 1.9434 & 1.5537 & 1.7340 & 2.0558 & 2.0127 & 1.5911 & 1.4703 \\
\hline Mean & 1.6595 & 1.7448 & 1.7066 & 1.8701 & 1.5292 & 1.7916 & 1.7180 & 1.8404 & 1.5602 & 1.6593 \\
\hline Total & 2.0338 & 2.0922 & 2.0668 & 2.1302 & 1.9116 & 2.1626 & 2.0713 & 2.0832 & 2.0474 & 2.0650 \\
\hline
\end{tabular}


Table 4 Morphological traits of the bermudagrass for each site along a latitudinal gradient used in analysis of variance (ANOVA)

\begin{tabular}{|c|c|c|c|c|c|}
\hline Traits & Source of variation & Sum of squares & $d f$ & $\mathrm{~F}$ & $P$-Value \\
\hline \multirow[t]{3}{*}{ Leaf length of erect shoots } & Among sites & $49,676.968$ & 15 & 7.669 & 0.000 \\
\hline & Within sites & $126,959.6$ & 294 & & \\
\hline & Total & $176,636.568$ & 309 & & \\
\hline \multirow[t]{3}{*}{ Leaf width of erect shoots } & Among sites & 13.256 & 15 & 4.098 & 0.000 \\
\hline & Within sites & 63.401 & 294 & & \\
\hline & Total & 76.657 & 309 & & \\
\hline \multirow[t]{3}{*}{ Internode length of erect shoots } & Among sites & $15,168.084$ & 15 & 8.711 & 0.000 \\
\hline & Within sites & $34,129.559$ & 294 & & \\
\hline & Total & $49,297.644$ & 309 & & \\
\hline \multirow[t]{3}{*}{ Diameter of erect shoots } & Among sites & 2.523 & 15 & 4.556 & 0.000 \\
\hline & Within sites & 10.852 & 294 & & \\
\hline & Total & 13.375 & 309 & & \\
\hline \multirow[t]{3}{*}{ Leaf length of stolon } & Among sites & $92,917.8$ & 15 & 9.562 & 0.000 \\
\hline & Within sites & $190,451.495$ & 294 & & \\
\hline & Total & $283,369.295$ & 309 & & \\
\hline \multirow[t]{3}{*}{ Leaf width of stolon } & Among sites & 18.252 & 15 & 5.462 & 0.000 \\
\hline & Within sites & 65.496 & 294 & & \\
\hline & Total & 83.748 & 309 & & \\
\hline \multirow[t]{3}{*}{ Internode length of stolon } & Among sites & $30,016.446$ & 15 & 4.8 & 0.000 \\
\hline & Within sites & $122,555.695$ & 294 & & \\
\hline & Total & $152,572.141$ & 309 & & \\
\hline \multirow[t]{3}{*}{ Diameter of stolon } & Among sites & 2.209 & 15 & 2.795 & 0.000 \\
\hline & Within sites & 15.491 & 294 & & \\
\hline & Total & 17.7 & 309 & & \\
\hline \multirow[t]{3}{*}{ Turf height } & Among sites & 6810.65 & 15 & 14.538 & 0.000 \\
\hline & Within sites & 9182.288 & 294 & & \\
\hline & Total & $15,992.938$ & 309 & & \\
\hline \multirow[t]{3}{*}{ Reproductive branch height } & Among sites & 6688.848 & 15 & 10.975 & 0.000 \\
\hline & Within sites & $11,945.886$ & 294 & & \\
\hline & Total & $18,634.735$ & 309 & & \\
\hline
\end{tabular}

Significant at $1 \%$ level $P<0.01$

Table 5 Soil features of different latitudes used in the diversity analysis

\begin{tabular}{|c|c|c|c|c|c|}
\hline Parameter & $\mathrm{N}$ & Minimum(g/kg) & Maximum(g/kg) & Mean \pm SD & $C V(\%)$ \\
\hline Total Nitrogen & 16 & 0.45 & 1.88 & $1.14 \pm 0.37$ & $32.27 \%$ \\
\hline Available Kalium & 16 & 0.11 & 0.35 & $0.20 \pm 0.08$ & $41.41 \%$ \\
\hline Available Nitrogen & 16 & 0.01 & 0.16 & $0.06 \pm 0.03$ & $53.86 \%$ \\
\hline Soil Organic Matter & 16 & 11.55 & 105.50 & $28.24 \pm 22.48$ & $79.59 \%$ \\
\hline Exchangeable Ca & 16 & 1.91 & 8.45 & $3.80 \pm 1.91$ & $50.29 \%$ \\
\hline Exchangeable Mg & 16 & 0.08 & 0.38 & $0.21 \pm 0.11$ & $50.92 \%$ \\
\hline Exchangeable $\mathrm{Na}$ & 16 & 0.06 & 0.33 & $0.14 \pm 0.07$ & $50.96 \%$ \\
\hline $\mathrm{pH}$ & 16 & 5.72 & 7.16 & $6.58 \pm 0.48$ & $7.24 \%$ \\
\hline
\end{tabular}


Table 6 Loadings of the significant morphological variables on two first principal components from analysis of C. dactylon morphological data

\begin{tabular}{llll}
\hline & Variable & \multicolumn{2}{l}{ Principal component } \\
\cline { 3 - 4 } & & 1 & 2 \\
\hline Erect shoot & Leaf length & 0.156 & -0.218 \\
& Leaf width & 0.157 & 0.195 \\
& Internode length & 0.172 & -0.096 \\
Stolon & diameter & 0.114 & 0.302 \\
& Leaf length & 0.126 & -0.257 \\
& Leaf width & 0.158 & 0.083 \\
& Internode length & 0.135 & 0.195 \\
& Diameter & 0.124 & 0.315 \\
& Turf height & 0.148 & -0.186 \\
& Reproductive branch height & 0.171 & -0.192 \\
\hline
\end{tabular}

morphological traits and soil properties are presented in Table 9. In general, contents of AK, AN and soil exchangeable $\mathrm{Mg}$ had significant effects on the bermudagrass morphological traits. The soil available kalium content was dramatically correlated with internodes length of erect shoots $(r=0.708)$, leaf width of erect shoots $(r=0.659)$ and reproductive branch height $(r=0.763)$; and positively with leaf length of stolon $(r=0.559)$ and erect shoots $(r=0.567)$.
AN was positively correlated with leaf length of erect shoots $(r=0.544)$, leaf width of erect shoots $(r=0.550)$ and reproductive branch height $(r=0.587)$. Meanwhile, exchangeable $\mathrm{Mg}$ was positively correlated with distance between internodes of erect shoots $(r=0.511)$, diameter of erect shoots $(r=0.601)$ and stolon $(r=0.622)$. Results indicate that bermudagrass morphological traits had a tendency to improve with the increase of soil exchangeable $\mathrm{Mg}, \mathrm{AN}$ and available potassium content.

\section{Discussion \\ Relationship between morphological diversity and latitude}

The measurements indicate a considerable morphological variation in bermudagrass populations along a latitudinal gradient. The morphological variability that exists within Cynodon spp. is well documented [13, 33]. The relationships between latitude and phenotypic variation (particularly phenology traits such as bud set) have been established previously in other species [34-38] and first published in Cynodon species. The presence of high morphological variation within regions and altitudes particularly above $2000 \mathrm{~m}$ a.s.l. indicated the potential of each region and high altitude zones for barley improvement and conservation in the country [39]. Our study has shown that morphological traits of Cynodon in the

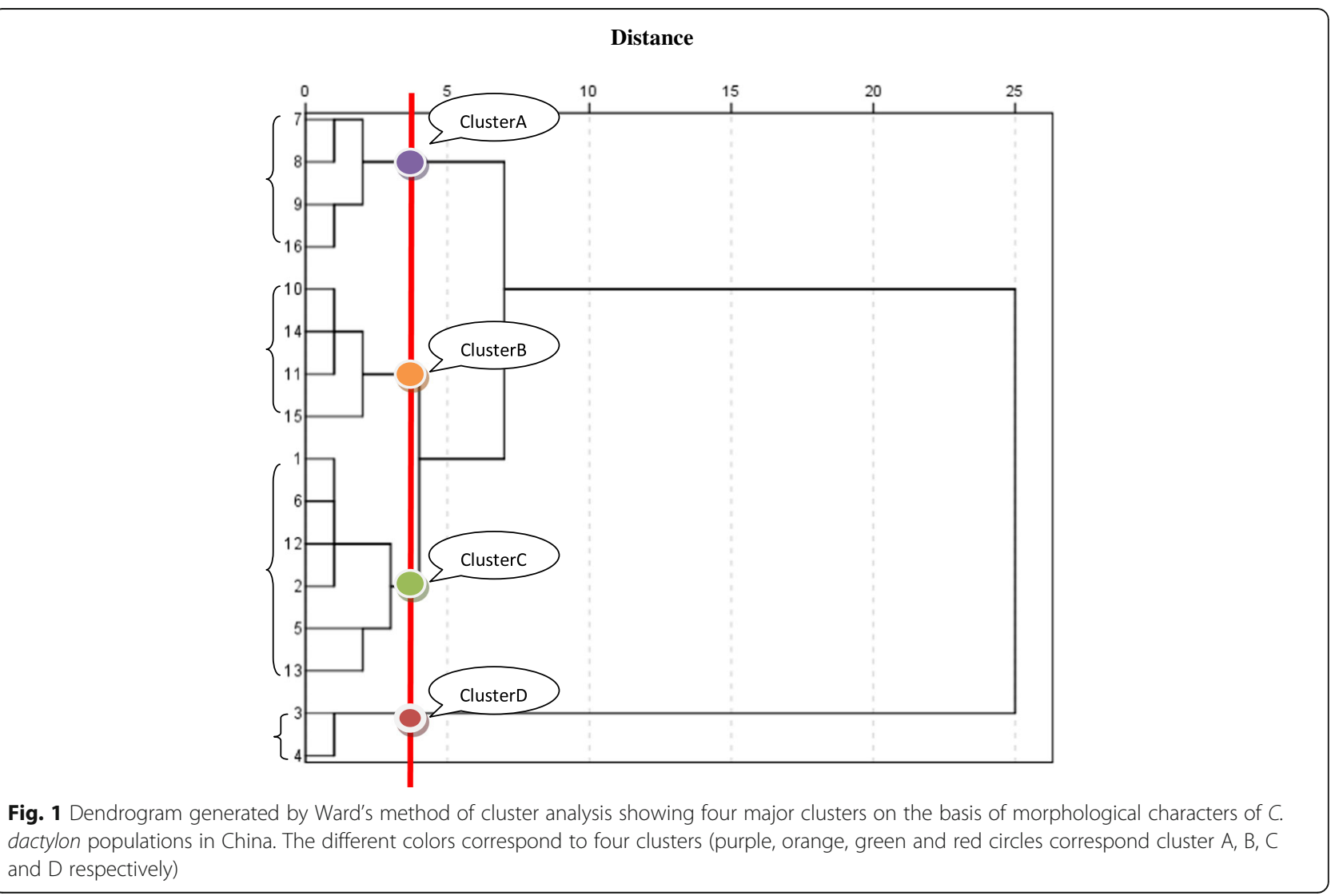




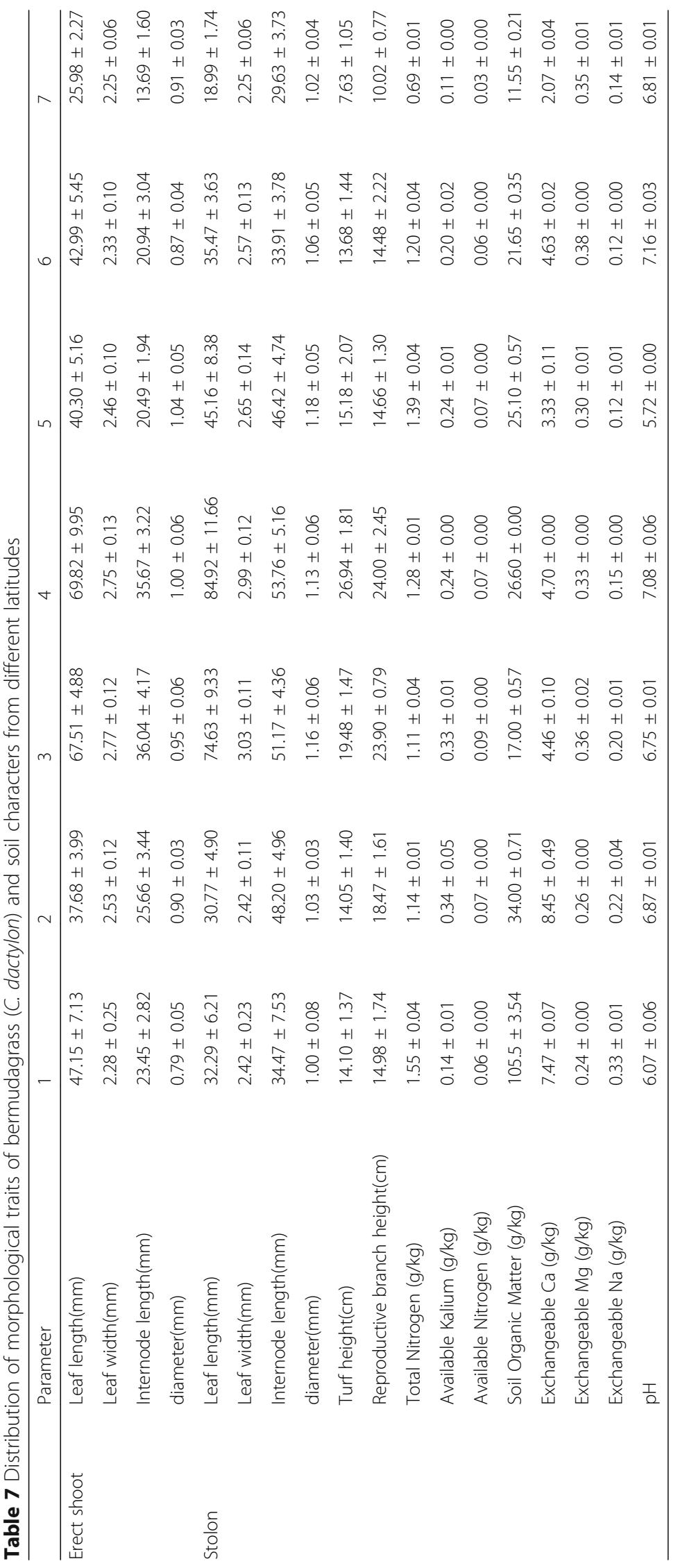




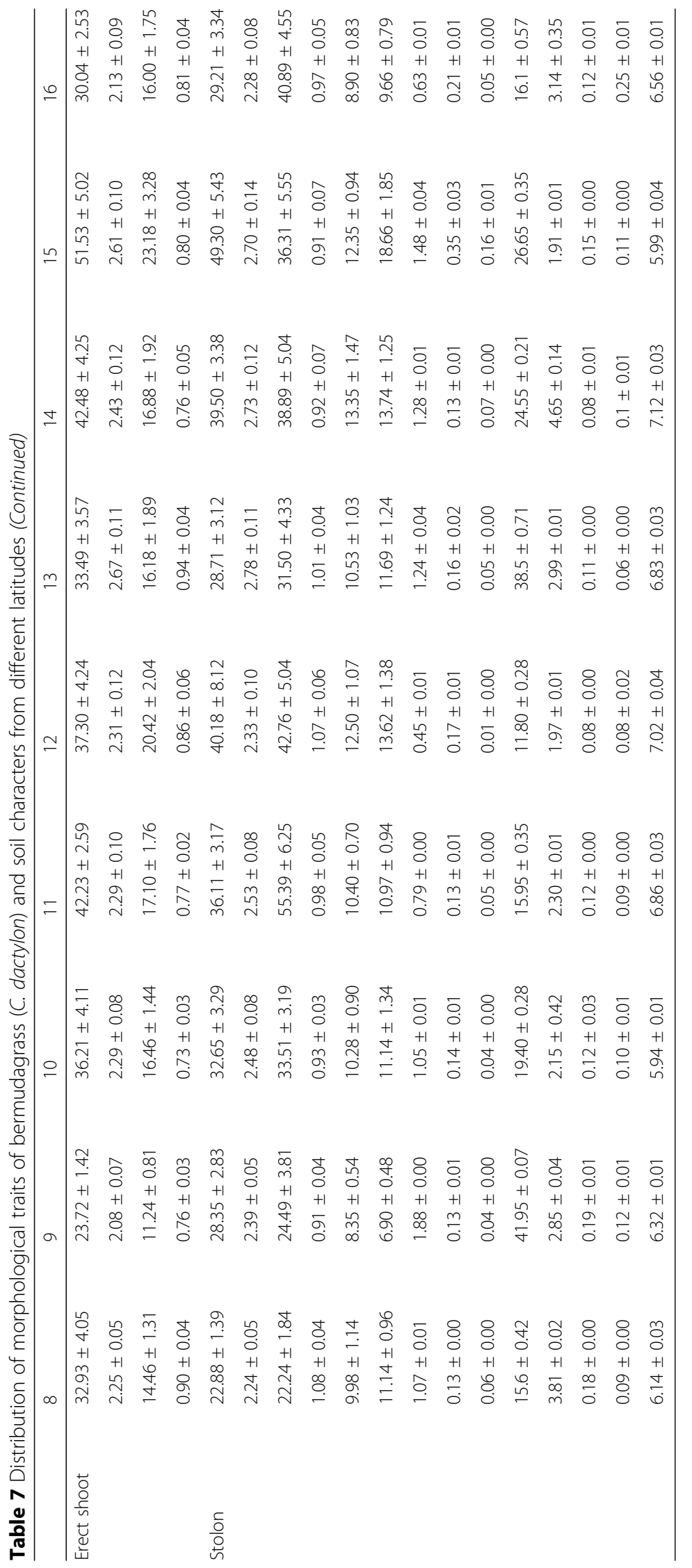


Table 8 Correlation coefficients between morphological traits of bermudagrass (C. dactylon) and meteorological characters

\begin{tabular}{|c|c|c|c|c|c|c|c|c|c|c|c|}
\hline \multirow[t]{2}{*}{ Traits } & \multicolumn{4}{|c|}{ Erect shoot } & \multicolumn{4}{|l|}{ Stolon } & \multirow{2}{*}{$\begin{array}{l}\text { Turf } \\
\text { height }\end{array}$} & \multirow{2}{*}{$\begin{array}{l}\text { Reproductive } \\
\text { branch } \\
\text { height }\end{array}$} & \multirow{2}{*}{$\begin{array}{l}\text { Diversity } \\
\text { index }\end{array}$} \\
\hline & $\begin{array}{l}\text { Leaf } \\
\text { length }\end{array}$ & $\begin{array}{l}\text { Leaf } \\
\text { width }\end{array}$ & $\begin{array}{l}\text { Internode } \\
\text { length }\end{array}$ & Diameter & $\begin{array}{l}\text { Leaf } \\
\text { length }\end{array}$ & $\begin{array}{l}\text { Leaf } \\
\text { width }\end{array}$ & $\begin{array}{l}\text { Internode } \\
\text { length }\end{array}$ & Diameter & & & \\
\hline $\begin{array}{l}\text { Annual average } \\
\text { temperature }\end{array}$ & $-.120^{*}$ & -0.053 & -0.089 & $-.181^{* *}$ & $-.193^{* *}$ & $-.160^{* *}$ & -0.002 & $-.181^{* *}$ & $-.199^{* *}$ & -0.061 & 0.253 \\
\hline $\begin{array}{l}\text { Annual maximum } \\
\text { temperature }\end{array}$ & -0.072 & -0.012 & -0.039 & $-.152^{* *}$ & $-.140^{*}$ & $-.114^{*}$ & 0.034 & $-.160^{* *}$ & $-.142^{*}$ & -0.004 & 0.296 \\
\hline $\begin{array}{l}\text { Annual minimum } \\
\text { temperature }\end{array}$ & $-.159^{* *}$ & -0.081 & $-.144^{*}$ & $-.215^{* *}$ & $-.235^{* *}$ & $-.188^{* *}$ & -0.039 & $-.210^{* *}$ & $-.251^{* *}$ & $-.114^{*}$ & 0.252 \\
\hline $\begin{array}{l}\text { Annual average } \\
\text { precipitation }\end{array}$ & $-.221^{* *}$ & -0.108 & $-.235^{* *}$ & $-.270^{* *}$ & $-.298^{* *}$ & $-.186^{* *}$ & -0.063 & $-.237^{* *}$ & $-.344^{* *}$ & $-.210^{* *}$ & 0.308 \\
\hline
\end{tabular}

***: significant at probability of 0.05 and 0.01 , respectively

high- and low-latitude populations tended to have greater size than those from the mid-latitudes in China. Cynodon morphological variation along environmental gradients demonstrated that their geographic patterns were shaped by environmental factors (climatic and edaphic gradients) and phylogenetic differences. Such weather condition contributed positively to rice yield by increasing the number of panicles per hill and the number of spikelets per panicle significantly [40]. Through regulating the metabolic activity and carbon allocation of plants [41], climate directly influences the morphology of leaves. In addition, climate may influence the geographic distribution of leaf traits indirectly by shaping the biogeography of the vegetation as well as soil nutrient availability $[42,43]$. The larger variance occurring within sites may be the result of micro-site variability, phylogenetic or historical effects, or biotic interactions and competition [44]. Polyploidization might be a driving force behind the divergence of Chinese Cynodon accessions and their biodiversity [45]. Adaptation in any species requires phenotypic variation in traits, but would not occur without genotypic variation. Within a species, this adaptation can theoretically be maintained through variable selection pressures from heterogeneous environments on a number of genes [46-49]. Genetic variation was expected based on previous reports of variation among $C$. dactylon accessions from geographic areas other than China [11, 33, 50-52].

\section{Effect of soil nutrients on wild bermudagrass morphological diversity}

Soil nutrients are important factors in evaluating soil quality, this approach, however, requires an understanding of the spatial variations of soil properties within fields. TN, available nitrogen and exchangeable $\mathrm{Ca}, \mathrm{Mg}$ varied significantly among different latitudes and some soil nutrients were significantly correlated with Cynodon morphological characters, indicating that the phenotypic diversity presented in this species is possibly due to the variation in soil characters. Plants at high latitude need more nutrients to achieve fast growth as a response to selection imposed by lower temperatures and compressed growing seasons $[53,54]$. In cold environments of high latitudes, sites can limit mineralization of organic matter, nutrient release from the mineral soil and biological nitrogen fixation. So more efficient nutrient resorption can be expected and resorbed nutrients are directly available for plant growth. It is postulated that in habitats with low nutrient availability, selection occurs for plant traits that result in higher nutrient conservation, including longer leaf and root life-span,

Table 9 Correlation coefficients between morphological traits of bermudagrass (C. dactylon) and soil characters

\begin{tabular}{|c|c|c|c|c|c|c|c|c|c|c|}
\hline \multirow[t]{2}{*}{ Traits } & \multicolumn{4}{|c|}{ Erect shoot } & \multicolumn{4}{|l|}{ Stolon } & \multirow{2}{*}{$\begin{array}{l}\text { Turf } \\
\text { height }\end{array}$} & \multirow{2}{*}{$\begin{array}{l}\text { Reproductive } \\
\text { branch } \\
\text { height }\end{array}$} \\
\hline & $\begin{array}{l}\text { Leaf } \\
\text { length }\end{array}$ & $\begin{array}{l}\text { Leaf } \\
\text { width }\end{array}$ & $\begin{array}{l}\text { Internode } \\
\text { length }\end{array}$ & Diameter & $\begin{array}{l}\text { Leaf } \\
\text { length }\end{array}$ & $\begin{array}{l}\text { Leaf } \\
\text { width }\end{array}$ & $\begin{array}{l}\text { Internode } \\
\text { length }\end{array}$ & Diameter & & \\
\hline Total Nitrogen & 0.158 & 0.162 & 0.084 & -0.048 & 0.147 & 0.336 & -0.262 & -0.169 & 0.194 & 0.130 \\
\hline Available Kalium & $0.567^{*}$ & $0.659^{* *}$ & $0.708^{* *}$ & 0.371 & $0.559^{*}$ & 0.476 & 0.497 & 0.299 & 0.497 & $0.763^{* *}$ \\
\hline Available Nitrogen & $0.544^{*}$ & $0.550^{*}$ & 0.456 & 0.084 & 0.437 & 0.496 & 0.170 & -0.037 & 0.338 & $0.587^{*}$ \\
\hline $\begin{array}{l}\text { Soil Organic } \\
\text { Matter }\end{array}$ & 0.078 & -0.050 & 0.090 & -0.180 & -0.097 & -0.017 & -0.174 & -0.163 & 0.085 & 0.040 \\
\hline Exchangeable Ca & 0.277 & 0.214 & 0.440 & 0.148 & 0.097 & 0.096 & 0.199 & 0.205 & 0.399 & 0.424 \\
\hline Exchangeable Mg & 0.385 & 0.287 & $0.511^{*}$ & $0.601^{*}$ & 0.351 & 0.257 & 0.153 & $0.622^{*}$ & 0.476 & 0.477 \\
\hline Exchangeable $\mathrm{Na}$ & 0.207 & -0.071 & 0.357 & -0.037 & 0.073 & -0.099 & 0.169 & 0.070 & 0.198 & 0.253 \\
\hline $\mathrm{PH}$ & 0.170 & 0.214 & 0.215 & 0.097 & 0.185 & 0.214 & 0.326 & 0.093 & 0.247 & 0.194 \\
\hline
\end{tabular}

***: significant at probability of 0.05 and 0.01 , respectively 
higher sclerophylly and more efficient nutrient resorption from senescing organs $[55,56]$. High level of organic matter supplied enough carbon, nitrogen and energy source to microbial growth. A close relationship has also been reported between soil fertility and microbial biomass [57, 58]. Internodes length of erect shoots, leaf width of erect shoots and reproductive branch height determined during the study have highly significant correlation (positive) with the soil available potassium. Exchangeable Mg and AN all were positively correlated with some morphological characters. Potassium (K), the third essential macro nutrient for higher plants, is involved in many important physiological processes in plants, and its functions have been shown to improve crop quality and the ability to resist adversities [59-61]. Plants from cold environments had significantly higher foliage $\mathrm{N}, \mathrm{P}$ and $\mathrm{Mg}$ concentrations when grown in high latitudes, and that this may be an adaptive feature that enhances metabolic activity and growth rates under low temperatures of their native habitats $[62,63]$.

\section{The evolution trend of bermudagrass morphological characteristics at different latitudes}

According to the results of analysis, a significant relationship was observed between the latitude and a number of bermudagrass morphological characteristics, indicating that latitude was the key factor influencing the evolution of Cynodon. Soil and climate factors play notable roles in the shaping of Cynodon phenotype as two important factors related to latitude. Phenotypic plasticity could result from heritable epigenetic effects that influence gene expression at different developmental stages or in different environments. Populations may need to respond to environmental change through phenotypic plasticity or adaptive evolution, by moving to a new area corresponding to environmental conditions they are adapted to, by genetically adapting to the new conditions, or by combinations of these responses. The complex evolutionary and breeding history has undoubtedly created both population structure and complex familial relationships [64]. Characterizing its germplasms for morphological characteristics diversity is an essential step in selection and breeding of this grass. These morphological characteristics such as leaf length, leaf width, turf height and reproductive branch height play important roles in the application of turfgrass. Bermudagrass in low- and high-latitude areas posses longer blade, higher turf height and reproductive branch height, which can be used to protect slope on both sides of highway and prevent soil erosion. Cynodon of mid-latitudes with lower turf height and reproductive branch height is excellent germplasm resources for lawn in the stadium and park. Thus, there are rich bermudagrass germplasm resources in different environmental conditions. Selecting representative germplasm resources in a wide range of geographical location can screen out more excellent germplasm resources. Due to long-term growth of wild bermudagrass in the bad environment, it goes through many generations of natural selection, and keep down features of survival and reproduction, which provide a rich material for breeding and breed improvement. The grass family is one of the most diverse plant taxa, and turf grasses have long been subjected to systematic studies using morphological characters [65]. Information resulting from this study, therefore, could be applied to various studies on bermudagrass such as genomics, cytogenetics, genetics and breeding.

\section{Conclusions}

In this study, these analyses against $C$. dactylon morphological traits and environment factors have revealed a remarkable variety of phenotypic resources at different latitudes which is important for the reserve and propagation of native Cynodon species. We also found that larger Cynodon morphological sizes were strongly associated with low- and high-latitudes among the 310 Cynodon accessions. For adaptive phenotypic plasticity to evolve, individuals must be capable of responding to latitude, and plastic genotypes must have a fitness advantage over genotypes that are incapable of altering their phenotypes. Our findings expand the current knowledge on morphological diversity of turf-type wild bermudagrass. Accessions of $C$. dactylon at different latitudes may further enrich the gene pool and adapt to more different environments, which are influenced by latitude-related soil characters such as soil available potassium, exchangeable $\mathrm{Mg}$ and available nitrogen and climate factors such as annual average precipitation and annual average temperature. The variation present in the Cynodon accessions may have significant contribution in $C$. dactylon breeding programs for various goals such as turf, forage, soil stabilization and remediation, as well as our understanding of the evolution of warm season grass.

\section{Abbreviations \\ AK: Available Kalium; AN: Available Nitrogen; ANOVA: One-way analysis of variance; CA: Cluster Analysis; CV: Coefficient of variation; P: Probability; PCA: Principal Component Analysis; PCs: Principal components; r: Correlation coefficients; SD: Standard deviation; SOM: Soil Organic Matter; TN: Total Nitrogen; UPGMA: Unweighted pair group mean average}

\section{Acknowledgements \\ We would like to thank Hui-Ping Tian and Rui-Yang Wei for their help in sample collection.}

\section{Availability of data and materials \\ The datasets used and/or analysed during the current study are available from the corresponding author on reasonable request.}

\section{Authors' contributions}

JX analyzed and interpreted the patient data and was a major contributor in writing the manuscript. All authors read and approved the final manuscript.

Ethics approval and consent to participate

Not applicable.

Consent for publication

Not applicable. 


\section{Competing interests}

The authors declare that they have no competing interests.

\section{Publisher's Note}

Springer Nature remains neutral with regard to jurisdictional claims in published maps and institutional affiliations.

\section{Received: 8 May 2018 Accepted: 13 September 2018}

\section{Published online: 28 September 2018}

\section{References}

1. Grime JP, Crick JC, Rincon JE. The ecological significance of plasticity. Symp Soc Exp Biol. 1986:40:25-9.

2. Aitken SN, Yeaman S, Holliday JA, Wang T, C urtis-Mclane S. Adaptation, migration or extirpation: climate change outcomes for tree populations. Evol Appl. 2008;1(1):95-111.

3. Hoffmann AA, Sgrò CM. Climate change and evolutionary adaptation. Nature. 2011;470(7335):479-85.

4. Alberto FJ, Aitken SN, Ricardo A, González-Martínez SC, Heikki H, Antoine K, et al. Potential for evolutionary responses to climate change - evidence from tree populations. Glob Chang Biol. 2013;19(6):1645.

5. Franks SJ, Weber JJ, Aitken SN. Evolutionary and plastic responses to climate change in terrestrial plant populations. Evol Appl. 2014;7(1):123.

6. Merilä J. Climate change, adaptation, and phenotypic plasticity: the problem and the evidence. Evol Appl. 2014;7(1):1-14.

7. Burton GW. Breeding bermuda grass for the Southeastern United States. Agron J. 1947;39.

8. Casler MD, Duncan RR, Casler MD, Duncan RR. Turfgrass biology, genetics and breeding. Q Rev Biol. 1976;51(Volume 51Number):286-7.

9. Huang CQ, Liu GD, Bai CJ, Wang WQ, Tang J, Yu DG. A study on the morphological diversity of 475 accessions of Cynodon dactylon. Acta Prataculturae Sinica. 2012.

10. Dong $\mathrm{M}$, Kroon HD. Plasticity in morphology and biomass allocation in Cynodon dactylon, a grass species forming Stolons and rhizomes. Oikos. 1994;70(1):99-106.

11. Roche MB. Characterisation of vegetative bermudagrasses (Cynodon spp.) for turf use in Australia. In: Agronomic; 2013.

12. Magni S, Gaetani M, Caturegli L, Leto C, Tuttolomondo T, Bella SL, et al. Phenotypic traits and establishment speed of 44 turf bermudagrass accessions. Acta Agric Scand. 2014;64(8):722-33.

13. Harlan JR, JMJ DW, Rawal KM, Felder MR, Richardson WL. Cytogenetic studies in Cynodon L. C. Rich. (Gramineae). Crop Sci. 1970;10(3):288-91.

14. Kole C. Wild crop relatives: genomic and breeding resources: millets and grasses. Wild Crop Relatives Genomic \& Breeding Resources Millets \& Grasses 2011;70(8):135-151

15. Nightingale ME, M. Lazarides, and C.M. Weiller. Flora of Australia. ABRS/ CSIRO publishing, Melbourne 2005;Vol. 44B.(Cynodon,):301-309.

16. Romani M, Piano E, Pecetti L. Collection and preliminary evaluation of native turfgrass accessions in Italy. Genet Resour Crop Evol. 2002;49(4):341-9.

17. Fischer AG. Latitudinal variations in organic diversity. Evolution. 1960;14(1): 64-81.

18. T. D. Evolution in the tropics. Am Sci. 1950;38:209-21.

19. Krauss KW, Allen JA. Factors influencing the regeneration of the mangrove Bruguiera gymnorrhiza (L.) Lamk. On a tropical Pacific island. For Ecol Manag. 2003:176(1):49-60.

20. Sylvia DM, Fuhrmann JJ, Hartel P, Zuberer DA. Principles and applications of soil microbiology. New Age International 1998;34(2):11-68.

21. Shi W, Muruganandam S, Bowman D. Soil microbial biomass and nitrogen dynamics in a turfgrass chronosequence: a short-term response to turfgrass clipping addition. Soil Biol Biochem. 2006;38(8):2032-42.

22. Yao $\mathrm{H}$, Wei S. Soil organic matter stabilization in turfgrass ecosystems: importance of microbial processing. Soil Biol Biochem. 2010;42(4):642-8.

23. Jenkinson DS. Microbial biomass in soil : measurement and turnover. Soil Biochem. 1981;5.

24. Singh JS, Raghubanshi AS, Singh RS, Srivastava SC. Microbial biomass acts as a source of plant nutrients in dry tropical forest and savanna. Nature. 1989; 338(6215):499-500

25. Smith JL, Paul EA, Bollag JM, Stotzky G. The significance of soil microbial biomass estimations. Soil Biochemistry. 1990;6.

26. Díaz-Raviña M, Acea MJ, Carballas T. Microbial biomass and its contribution to nutrient concentrations in forest soils. Soil Biol Biochem. 1993;25(1):25-31.
27. Zak DR, Pregitzer KS. Spatial and temporal variability of nitrogen cycling in northern lower Michigan. For Sci. 1990:36(2):367-80.

28. Smith JL, Papendick RI, Bezdicek DF, Lynch JM, Metting FB Jr. Soil organic matter dynamics and crop residue management; 1992. p. 65-94.

29. Metting FB Jr. Soil microbial ecology: applications in agricultural and environmental management. Soil Sci. 1992;157(3):195-7.

30. Fu W, Tunney H, Zhang C. Spatial variation of soil nutrients in a dairy farm and its implications for site-specific fertilizer application. Soil Tillage Res. 2010;106(2):185-93.

31. Tesfahunegn GB, Tamene L, Vlek PLG. Catchment-scale spatial variability of soil properties and implications on site-specific soil management in northern Ethiopia. Soil Tillage Res. 2011;117(6):124-39.

32. K. LR. Chemical analysis method of agricultural soil, vol. 2000. Beijing: China Agricultural Science Press; 2000. p. 106-7.

33. Harlan JR, JMJD W. Sources of Variation in Cynodon dactylon (L). Pers. Crop Sci. 1969;9(6).

34. Luquez V, Hall D, Albrectsen BR, Karlsson J, Ingvarsson P, Jansson S. Natural phenological variation in aspen ( Populus tremula ): the SwAsp collection. Tree Genet Genomes. 2008:4(2):279-92.

35. Soolanayakanahally RY, Guy RD, Silim SN, Drewes EC, Schroeder WR. Enhanced assimilation rate and water use efficiency with latitude through increased photosynthetic capacity and internal conductance in balsam poplar (Populus balsamifera L.). Plant Cell Environ. 2009;32(12):1821-32.

36. Soolanayakanahally RY, Guy RD, Silim SN, Song M. Timing of photoperiodic competency causes phenological mismatch in balsam poplar (Populus balsamifera L.). Plant Cell Environ. 2012;36(1):116-27.

37. Keller SR, Soolanayakanahally RY, Guy RD, Silim SN, Olson MS, Tiffin P. Climate-driven local adaptation of ecophysiology and phenology in balsam poplar, Populus balsamifera L. (Salicaceae). Am J Bot. 2011;98(1):99-108.

38. Cooke JE, Eriksson ME, Junttila O. The dynamic nature of bud dormancy in trees: environmental control and molecular mechanisms. Plant Cell Environ. 2012;35(10):1707.

39. Abebe TD, Bauer AM, Léon J. Morphological diversity of Ethiopian barleys (Hordeum vulgare L.) in relation to geographic regions and altitudes. Hereditas. 2010;147(4):154-64.

40. Park SZ, Lee EW. Lee BW. Varietal differences in agronmic characters under different altitudinal locations with equal latitude in Paddy Rice 한국작물학 회지. South Korea's j. 1983;28(28):164-72.

41. Moles AT, Perkins SE, Laffan SW, Flores-Moreno H, Awasthy M, Tindall ML, et al. Which is a better predictor of plant traits: temperature or precipitation? J Veg Sci. 2014;25(5):1167-80

42. lii FSC, Matson PA, Mooney HA. Principles of Terrestrial Ecosystem Ecology. New York: Springer; 2011. p. 369-97.

43. Ordoñez JC, Bodegom PMV, Witte JPM, Wright IJ, Reich PB, Aerts R. A global study of relationships between leaf traits, climate and soil measures of nutrient fertility. Glob Ecol Biogeogr. 2009:137-49.

44. Gómez-Ordóñez E, Jiménez-Escrig A, Rupérez P. Dietary fibre and physicochemical properties of several edible seaweeds from the northwestern Spanish coast. Food Res Int. 2010:43(9):2289-94.

45. Wu YQ, Taliaferro CM, Bai GH, Martin DL, Anderson JA, Anderson MP, et al. Genetic analyses of Chinese accessions by flow cytometry and AFLP markers. Crop Sci. 2006;46(2).

46. Stettler RF, Bradshaw HD, Jr, Heilman PE, Hinckley TM. Biology of Populus and its implications for management and conservation. Biology of \& Its Implications for Management \& Conservation 1996:542.

47. Kawecki TJ, Ebert D. Conceptual issues in local adaptation. Ecol Lett. 2004; 7(12):1225-41.

48. Savolainen O, Pyhäjärvi T, Knürr T. Gene flow and local adaptation in trees. Ann Rev Ecol Evol Syst. 2007:38(1):595-619.

49. Corre VL, Kremer A. The genetic differentiation at quantitative trait loci under local adaptation. Mol Ecol. 2012;21(7):1548-66.

50. Juska FV, Hanson AA. Evaluation of Bermudagrass varieties for generalpurpose turf. U S Dep Agr Agr Handbook 1964.

51. Kneebone WR. Breeding seeded varieties of Bermudagrass for turfgrass use. 1973.

52. Harlan JR. Cynodon species and their value for grazing and hay. Herbage Abstracts 1970.

53. Sterner RW, Elser JJ. Ecological Stoichiometry: The Biology of Elements From Molecules to The Biosphere; 2002. p. 225-6.

54. Kerkhoff A, Enquist B, Elser J, Fagan W. Plant allometry, stoichiometry and the temperature-dependence of primary productivity. Glob Ecol Biogeogr. 2005;14(6):585-98 
55. Chapin FS,I. The mineral nutrition of wild plants. Ann Rev Ecol Syst. 1980; 11(1):233-60.

56. Eckstein RL, Karlsson PS, Weih M. Leaf life span and nutrient resorption as determinants of plant nutrient conservation in temperate-arctic regions. New Phytol. 1999;143(1):177-89.

57. Pankhurst CE, Hawke BG, Mcdonald HJ, Kirkby CA, Buckerfield JC, Michelsen $\mathrm{P}$, et al. Evaluation of soil biological properties as potential bioindicators of soil health. Aust J Exp Agric. 1995;35(7):1015-28.

58. Hofman J, Dusek L, Klánová J, Bezchlebová J, Holoubek I. Monitoring microbial biomass and respiration in different soils from the Czech Republic--a summary of results. Environ Int. 2004;30(1):19-30.

59. Liu J, Zhu JK. An Arabidopsis mutant that requires increased calcium for potassium nutrition and salt tolerance. Proc Natl Acad Sci U S A. 1997; 94(26):14960-4.

60. Pettigrew WT. Potassium influences on yield and quality production for maize, wheat, soybean and cotton. Physiol Plant. 2008;133(4):670-81.

61. H. M. Mineral nutrition of higher plants, 2nd. San Diego: Academic press; 1995.

62. Reich PB, Oleksyn J, Tjoelker MG. Needle respiration and nitrogen concentration in scots pine populations from a broad latitudinal range: a common garden test with field-grown trees. Funct Ecol. 1996;10(6):768-76.

63. Weih M, Karlsson PS. Growth response of mountain birch to air and soil temperature: is increasing leaf-nitrogen content an acclimation to lower air temperature? New Phytol. 2001:150(1):147-55.

64. Yu J, Buckler ES. Genetic association mapping and genome organization of maize. Curr Opin Biotechnol. 2006;17(2):155-60.

65. Watson L DMJ. The grass genera of the world: descriptions, illustrations, identification, and information retrieval; including synonyms, morphology, anatomy, physiology, phytochemistry, cytology, classification, pathogens, world and local distribution, and references. Published on the Internet. 1992. http://www.delta-intkey.com/grass/intro.htm. Accessed 9 Jan 2015.

Ready to submit your research? Choose BMC and benefit from:

- fast, convenient online submission

- thorough peer review by experienced researchers in your field

- rapid publication on acceptance

- support for research data, including large and complex data types

- gold Open Access which fosters wider collaboration and increased citations

- maximum visibility for your research: over $100 \mathrm{M}$ website views per year

At $\mathrm{BMC}$, research is always in progress.

Learn more biomedcentral.com/submissions 